\title{
Audible Alarm Device
}

National Cancer Institute

\section{Source}

National Cancer Institute. Audible Alarm Device. NCI Thesaurus. Code C49814.

A device designed to signal the occurrence of a particular event by making a sound. 